\title{
The Role of CED-3-Related Cysteine Proteases in Apoptosis of Cerebellar Granule Cells
}

\author{
Basil A. Eldadah, ${ }^{1,2}$ Alexander G. Yakovlev, ${ }^{1,3}$ and Alan I. Faden ${ }^{1,3}$ \\ ${ }^{1}$ Georgetown Institute for Cognitive and Computational Sciences, ${ }^{2}$ Interdisciplinary Program in Neuroscience, and \\ ${ }^{3}$ Department of Neurology, Georgetown University Medical Center, Washington, DC 20007
}

The CED-3-related cysteine proteases (CRCPs) have been implicated as mediators of apoptosis, primarily in hematogenous cell systems, but their role in neuronal apoptosis remains unclear. The present study examined the role of two CRCP families-CPP32- and interleukin-1 $\beta$ converting enzyme (ICE)like cysteine proteases-in apoptosis of cerebellar granule cells (CGCs) caused by withdrawal of serum and/or potassium $\left(\mathrm{K}^{+}\right)$. Serum deprivation potentiated apoptosis caused by $\mathrm{K}^{+}$withdrawal, reducing cell viability by approximately one half of control values after $12 \mathrm{hr}$ as measured by calcein fluorescence. Cell death after serum $/ \mathrm{K}^{+}$deprivation was significantly attenuated by the CPP32-like inhibitor z-DEVD-fmk; however, the ICE-like inhibitor z-YVAD-fmk had only slightly protective effects at the highest concentration used. Both inhibitors reduced CPP32-like activity directly in an in vitro fluorometric assay system, although z-DEVD-fmk showed much greater potency. $\mathrm{K}^{+}$and serum $/ \mathrm{K}^{+}$deprivation each were accompanied by increased CPP32-like activity; however, ICE-like activity was absent after $12 \mathrm{hr}$ of serum and/or $\mathrm{K}^{+}$deprivation. CPP32 mRNA levels were unchanged after $\mathrm{K}^{+}$deprivation but increased after serum and combined serum $/ \mathrm{K}^{+}$withdrawal as measured by reverse transcription-PCR (RT-PCR), with peak values at $4 \mathrm{hr}$ reaching $210 \pm 37 \%$ and $269 \pm 42 \%$ of control levels, respectively. In contrast, ICE mRNA was undetectable by RT-PCR. These results are consistent with the hypothesis that CPP32-like proteases play an important role in apoptosis of CGCs caused by deprivation of $\mathrm{K}^{+}$or serum $/ \mathrm{K}^{+}$.

Key words: CPP32; ICE; CED-3; cerebellar granule cells; RT-PCR; protease activity; calcein AM
Apoptosis is a type of cell death characterized histologically by nuclear condensation, chromatin margination, plasma membrane blebbing, and fragmentation into apoptotic bodies (Kerr et al., 1972; Bredeson, 1995). These changes are often accompanied by internucleosomal cleavage of genomic DNA (Wyllie, 1980; Batistatou and Greene, 1993; D'Mello et al., 1993).

Apoptosis occurs in the nervous system under both physiological and pathological conditions. During development, for example, a significant proportion of neurons die by apoptosis to permit matching cell numbers with their targets (Oppenheim, 1991). Apoptotic cell death also occurs after acute insults to the CNS, such as trauma (Rink et al., 1995; Eldadah et al., 1996) or ischemia (Linnik et al., 1993; Li et al., 1995), as well as in chronic degenerative conditions (Hartley et al., 1994; Portera-Cailliau et al., 1995; Rabizadeh et al., 1995).

Many of the genes known to regulate apoptotic cell death were originally identified in the nematode Caenorhabditis elegans, in which three genes-ced-3, ced-4, and ced-9-are thought to play critical roles (Ellis and Horvitz, 1986). CED-3 promotes apoptosis, and the cysteine protease interleukin- $1 \beta$ converting enzyme (ICE) was its first identified mammalian homolog (Thornberry et al., 1992). Subsequently, nine additional CED-3-related cysteine proteases (CRCPs) have been defined and categorized into two families on the basis of their DNA coding sequences (Alnemri et

Received Jan. 2, 1997; revised May 30, 1997; accepted June 4, 1997.

This study was supported by a cooperative research agreement with the Department of Defense (DAMD-17-93-V-3018). We thank Dr. Svetlana Ivanova for help in preparing CGC cultures, Jason Allen for assistance with cell viability assays, and Dr. Gary Chase for help with statistical analyses.

Correspondence should be addressed to Alan I. Faden, NRB EP04, 3970 Reservoir Road NW, Georgetown University Medical Center, Washington, DC 20007.

Copyright (C) 1997 Society for Neuroscience $\quad 0270-6474 / 97 / 176105-\bullet \$ 05.00 / 0$ al., 1996). The ICE-like family includes ICE, ICH-2/TX/ICE ${ }_{\text {rel }} \mathrm{II}$ (Faucheu et al., 1995; Kamens et al., 1995; Munday et al., 1995),

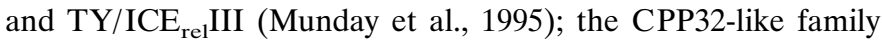
consists of CPP32/Yama/apopain (Fernandes-Alnemri et al., 1994; Tewari et al., 1995), ICH-1/Nedd2 (Kumar et al., 1994; Wang et al., 1994), MCH2-5 (Fernandes-Alnemri et al., 1995a,b, 1996), and ICE-LAP6/MCH6 (Duan et al., 1996).

The cleavage of putative CRCP substrates likely contributes to the morphological and biochemical changes characteristic of apoptosis. For example, poly(ADP-ribose) polymerase (PARP) and DNA-dependent protein kinase are two nuclear enzymes that modify cellular proteins in response to DNA damage (Kaufmann et al., 1993; Casciola-Rosen et al., 1996). Their cleavage by CPP32-like proteases may interfere with DNA repair mechanisms that would otherwise counteract apoptotic DNA degradation (Martin and Green, 1995). Likewise, cleavage of cytoskeletal proteins like $\beta$-actin may cause membrane blebbing and cellular fragmentation, leading to the appearance of apoptotic bodies (Martin and Green, 1995; Kayalar et al., 1996).

Most studies implicating CRCPs as critical mediators of apoptosis have involved hematogenous cell lines (Zhu et al., 1995; Enari et al., 1996; Jacobson et al., 1996), and little is known about their role in neuronal systems. In the present study, we sought to determine whether CRCPs participate in the apoptotic death of cerebellar granule cells (CGCs) after withdrawal of serum and/or $\mathrm{K}^{+}$(Miller and Johnson, 1996). To answer this question, we assessed the degree of apoptosis after serum and/or $\mathrm{K}^{+}$deprivation and examined whether selective peptide-fluoromethylketone inhibitors of CRCPs could modify this response. In addition, we measured changes in CRCPs in response to three deprivation 
conditions at the level of enzymatic activity and mRNA expression.

\section{MATERIALS AND METHODS}

Culturing of CGCs. Primary cultures of CGCs were prepared essentially as described by Thangnipon et al. (1983). Briefly, cerebella from 8-d-old Sprague Dawley rat pups (Taconic, Germantown, NY) were dissected from their meninges in Krebs-Ringer bicarbonate buffer containing $0.3 \%$ bovine serum albumin (BSA) (Life Technologies, Gaithersburg, MD). The cerebella were minced and dissociated in $1800 \mathrm{U} / \mathrm{ml}$ trypsin (Sigma, St. Louis, $\mathrm{MO}$ ) at $37^{\circ} \mathrm{C}$ for $20 \mathrm{~min}$. After the addition of $200 \mathrm{U} / \mathrm{ml}$ DNase I (Sigma) and $3600 \mathrm{U} / \mathrm{ml}$ soybean trypsin inhibitor (Life Technologies) to the suspension, cells were triturated 25 times through a $5 \mathrm{ml}$ pipette. After the tissue settled for 5-10 min, the supernatant was collected, and the remaining tissue pellet was retriturated as before. The combined supernatants were then centrifuged through a $4 \%$ BSA layer. The cell pellet was resuspended in seeding medium, which consisted of Basal Medium Eagle (BME) (Life Technologies), 2 mm glutamine (Biofluids, Rockville, MD), $50 \mu \mathrm{g} / \mathrm{ml}$ gentamicin sulfate (Biofluids), $10 \%$ fetal bovine serum (Hyclone Laboratories, Logan, UT), and except where indicated, $25 \mathrm{~mm} \mathrm{KCl} \mathrm{(Sig-}$ ma). Cells were seeded at $1.5 \times 10^{5}$ cells $/ \mathrm{cm}^{2}$ onto $60 \mathrm{~mm}$ or $100 \mathrm{~mm}$ tissue culture dishes (Corning, Corning, NY) precoated with poly-L-lysine (30-70 $\mathrm{kDa}$, Sigma). After incubating for $24 \mathrm{hr}$ at $37^{\circ} \mathrm{C}$ in $5 \% \mathrm{CO}_{2}, 10 \mu \mathrm{M}$ cytosine- $\beta$-D-arabinofuranoside (Sigma) was added, and incubation was continued for 6 more d. At this time, cells were washed once in BME followed by the addition of one of the following media: $25 \mathrm{mM} \mathrm{KCl}$ conditioned medium $(\mathrm{K} 25+\mathrm{S})$, seeding medium without serum $(\mathrm{K} 25-\mathrm{S}), 5$ $\mathrm{mm} \mathrm{KCl}$ conditioned medium $(\mathrm{K} 5+\mathrm{S})$, or seeding medium without serum or supplemented $\mathrm{KCl}(\mathrm{K} 5-\mathrm{S})$. It was necessary to use 7-d-old conditioned media for serum-containing treatments, because addition of fresh serum is toxic to mature CGC cultures (Schramm et al., 1990). Conditioned media were prepared by collecting $\mathrm{K} 25+\mathrm{S}$ or $\mathrm{K} 5+\mathrm{S}$ culture media after $7 \mathrm{~d}$ in vitro, followed by centrifugation at $180 \times g$ for $4 \mathrm{~min}$ and filtration through $0.22 \mu \mathrm{m}$ cellulose acetate. Conditioned media were stored at $4^{\circ} \mathrm{C}$ until they were used.

Assessment of cell viability. Cell viability was measured by retention and deesterification of calcein AM (Molecular Probes, Eugene, OR). This method has been used previously to estimate the extent of apoptosis in CGCs (Miller and Johnson, 1996) and is simpler and more consistent than other techniques such as terminal deoxynucleotidyltransferasemediated dUTP-biotin nick end labeling (TUNEL) (Gavrieli et al., 1992). Cells were washed once in Locke's buffer containing (in mM): 154 $\mathrm{NaCl}$, 5.6 KCl, $3.6 \mathrm{NaHCO}_{3}, 2.3 \mathrm{CaCl}_{2}, 1.2 \mathrm{MgCl}_{2}$, 5.6 glucose, 5 HEPES, pH 7.4. After loading with $5 \mu \mathrm{M}$ calcein AM in Locke's buffer for $30 \mathrm{~min}$, fluorescence was visualized on a Zeiss Axiovert 135 inverted microscope using $488 \mathrm{~nm}$ excitation and $520 \mathrm{~nm}$ emission filters. Four to five random $200 \times$ fields per dish were photographed, and viability was determined by counting the number of fluorescent cells in each field.

DNA fragmentation analysis. Genomic DNA was extracted and analyzed as described previously (Eldadah et al., 1996). Briefly, after each 60 $\mathrm{mm}$ dish was stained with calcein AM and photographed, cells were lysed in $2 \mathrm{ml} 7 \mathrm{M}$ guanidine hydrochloride (Life Technologies). This lysate was mixed with $1 \mathrm{ml}$ Wizard Minipreps DNA Purification Resin (Promega, Madison, WI) and centrifuged at $2000 \times g$. The resin-DNA pellet was resuspended in washing solution $(90 \mathrm{~mm} \mathrm{NaCl}, 9 \mathrm{~mm}$ Tris-HCl, $\mathrm{pH} 7.4$, $2.25 \mathrm{~mm}$ EDTA, and 55\% ethanol) and passed through a Wizard Minicolumn (Promega) mounted onto a vacuum manifold. The Minicolumn was washed twice with $3 \mathrm{ml}$ washing solution and centrifuged at $5000 \times$ $g$ for $2 \mathrm{~min}$. DNA was eluted from the Minicolumn by the addition of 50 $\mu l$ of deionized water and centrifugation over a new microfuge tube at $5000 \times g$ for $2 \mathrm{~min}$. Residual RNA was digested by incubation for $15 \mathrm{~min}$ at $37^{\circ} \mathrm{C}$ with $2 \mu \mathrm{g}$ of RNase A (5 Prime $\rightarrow 3$ Prime, Boulder, CO). DNA concentrations were estimated by preparing dilutions of each sample in 1:10,000 SYBR Green I Nucleic Acid Stain (Molecular Probes) and comparing the fluorescent signals with those of sonicated herring sperm DNA standards. Two hundred nanograms of each DNA sample were loaded onto a $1.5 \%$ agarose gel (United States Biochemicals, Cleveland, $\mathrm{OH}$ ) in $1 \times$ tris-borate-EDTA buffer (TBE) (Digene Diagnostics, Beltsville, MD) containing $0.5 \mu \mathrm{g} / \mathrm{ml}$ ethidium bromide. After electrophoresis at $4 \mathrm{~V} / \mathrm{cm}$, DNA was visualized by $300 \mathrm{~nm}$ transillumination on a Speedlight Gel Documentation System (Hoefer, San Francisco, CA).

Inhibition of CRCPs. CGC cultures were preincubated for $1 \mathrm{hr}$ with DMSO vehicle or the indicated concentrations of z-DEVD-fmk, z-YVAD-fmk, or z-FA-fmk (Enzyme Systems Products, Dublin, CA). After cultures were washed once with BME, K5-S media containing inhibitor or vehicle was added. The concentration of DMSO in all cultures was $0.8 \%$. The combined serum $/ \mathrm{K}^{+}$deprivation condition was chosen to investigate the effects of CRCP inhibition because of its potent induction of cell death and DNA fragmentation. At selected time points, cells were stained with calcein AM and photographed.

Assay for CRCP activity in CGCs. CRCP activity was measured essentially as described by Nicholson et al. (1995). After the medium from each $10 \mathrm{~cm}$ dish was aspirated, $500 \mu$ lysis buffer was added that consisted of $10 \mathrm{~mm}$ HEPES-KOH, pH 7.2, 2 mM EDTA, 0.1\% CHAPS (Sigma), $5 \mathrm{~mm}$ dithiothreitol (DTT) (Sigma), $1 \mathrm{~mm}$ phenylmethylsulfonyl fluoride (Sigma), $10 \mu \mathrm{g} / \mathrm{ml}$ pepstatin A (Sigma), $10 \mu \mathrm{g} / \mathrm{ml}$ aprotinin (Calbiochem, La Jolla, CA), and $20 \mu \mathrm{g} / \mathrm{ml}$ leupeptin (Sigma). Cell lysates were scraped into microfuge tubes and frozen on dry ice. Lysates were then thawed, triturated 10 times, and centrifuged at $13,000 \times g$ for $30 \mathrm{~min}$. Supernatants were transferred to new tubes and stored at $-80^{\circ} \mathrm{C}$ until they were used. Protein concentrations were estimated by the Bradford method (Bio-Rad, Hercules, CA) according to the manufacturer's recommendations. To assay for CPP32- or ICE-like activity, $20 \mu \mathrm{g}$ of cytosolic protein was incubated in a microtiter plate with the fluorescent tetrapeptide substrate Ac-DEVD-AMC or Ac-YVAD-AMC $(20 \mu \mathrm{M})$ (Bachem, Torrance, CA), respectively. All reactants were diluted in lysis buffer. Free aminomethylcoumarin (AMC) accumulation, which resulted from cleavage of the aspartate-AMC bond, was measured using a CytoFluor II fluorometer (PerSeptive Biosystems, Framingham, MA) at 360 $\mathrm{nm}$ excitation and 460 emission wavelengths. Serial dilutions of AMC (Aldrich, Milwaukee, WI) were used as standards.

CPP32-like protease activity was also assessed by the PARP cleavage method (Nicholson et al., 1995). ${ }^{35}$ S-labeled recombinant PARP was generated in a coupled in vitro transcription/translation system (Promega) using an expression plasmid encoding the full-length PARP protein (a gift of M. Smulson, Georgetown University). For the cleavage assay, $0.5 \mu \mathrm{l}\left[{ }^{35} \mathrm{~S}\right]-\mathrm{PARP}$ was added to $10 \mu \mathrm{g}$ of cytosolic protein and diluted to $20 \mu \mathrm{l}$ with lysis buffer. Reaction mixtures were incubated for 1 hr at $37^{\circ} \mathrm{C}$ and then terminated by addition of protein gel loading buffer containing SDS. After denaturation at $95^{\circ} \mathrm{C}$ for $5 \mathrm{~min}$, samples were electrophoresed in a $10 \%$ SDS-polyacrylamide gel. The gel was dried and exposed onto a phosphorimaging screen, which was scanned on a Storm 840 imaging system (Molecular Dynamics, Sunnyvale, CA) and visualized using ImageQuant version 1.1 (Molecular Dynamics).

Reverse transcription-PCR (RT-PCR). Qualitative RT-PCR was performed to determine the presence of CPP32 and ICE mRNA. Total RNA from CGCs or whole adult rat brain was isolated by the guanidinium isothiocyanate-acidic phenol-chloroform method (Chomczynski and Sacchi, 1987), and RNA concentrations were estimated spectrophotometrically. Then, RNA was treated with RNase-free DNase I (Promega) at $0.2 \mathrm{U} / \mu \mathrm{g}$ RNA for $1 \mathrm{hr}$ at $37^{\circ} \mathrm{C}$. A $1.25 \mu \mathrm{g}$ RNA aliquot was reverse-transcribed at $42^{\circ} \mathrm{C}$ for $2 \mathrm{hr}$ in a $20 \mu \mathrm{l}$ reaction volume containing 200 U Muloney Murine Leukemia Virus Reverse Transcriptase (Life Technologies), $4 \mu \mathrm{M}$ oligo-dT(15), $4 \mu \mathrm{M}$ random primers (10-mer), 500 $\mu \mathrm{M}$ dNTPs (Sigma), and $5 \mathrm{~mm}$ DTT. PCR was performed using one tenth of the reverse transcription reaction volume and $30 \mathrm{pmol}$ of the following oligonucleotides: 5'-GGTATTGAGACAGACAGTGG-3' (CPP32 sense primer); 5'-CATGGGATCTGTTTCTTTGC-3' (CPP32 antisense primer); 5'-CACATTGAAGTGCCCAAGCT-3' (ICE sense primer); 5'-TCCAAGTCACAAGACCAGGC-3' (ICE antisense primer).

PCR was performed using 30 cycles of the following program: initial denaturation at $95^{\circ} \mathrm{C}$ for $2 \mathrm{~min}, 94^{\circ} \mathrm{C}$ for $30 \mathrm{sec}, 55^{\circ} \mathrm{C}$ for $15 \mathrm{sec}, 72^{\circ} \mathrm{C}$ for $45 \mathrm{sec}$, and a final primer extension at $72^{\circ} \mathrm{C}$ for $2 \mathrm{~min}$. One third of each reaction product was loaded onto a $2 \%$ agarose gel in $1 \times$ TBE buffer containing $0.5 \mu \mathrm{g} / \mathrm{ml}$ ethidium bromide. After electrophoresis at $5 \mathrm{~V} / \mathrm{cm}$, DNA was visualized as described for DNA fragmentation analysis above.

Because ICE mRNA could not be detected, semiquantitative RTPCR was performed for CPP32 only using 25 cycles of the program described above. As an internal control, 20 cycles of PCR were performed for histone $4 \mathrm{G}$ using the following oligonucleotides: 5'ATGTCTGGACGAGGGAAAGGCGGCA-3' (sense primer) and 5' CCGTGACCGTCTTGCGCTTGGCGTG-3' (antisense primer).

The number of cycles selected for each primer pair was found to produce a linear relationship between the amounts of input RNA and resulting PCR products. One third of each reaction volume was loaded onto a $2 \%$ agarose gel (United States Biochemicals) in $1 \times$ tris-acetateEDTA buffer (Life Technologies) at $5 \mathrm{~V} / \mathrm{cm}$. The gel was soaked in 1:10,000 SYBR Green I Nucleic Acid Stain (Molecular Probes) for 30 min at room temperature and scanned on a Storm 840 imaging system. 
Densitometry of PCR products was performed using the volume function and object average background correction in ImageQuant version 1.1.

Assessment of CRCP inhibitor specificity. Inhibition of CPP32-like protease activity by z-DEVD-fmk, z-YVAD-fmk, or z-FA-fmk was determined by fluorometric analysis. Etoposide-treated THP-1 human monocytes (American Type Culture Collection, Rockville, MD) were used as a source of CPP32-like protease activity in this assay (Zhu et al., 1995). After THP-1 cells were pelleted and resuspended in lysis buffer, cytosolic protein extracts were prepared as described above (assay for CRCP activity in CGCs). Ten micrograms of protein were mixed with increasing concentrations of inhibitor and assayed as above.

Statistical analyses. For cell viability assays after serum and/or $\mathrm{K}^{+}$ deprivation (Fig. 1B), multiple pairwise comparisons across groups were performed by ANOVA followed by a one-tailed Tukey's test. For cell viability studies after CRCP inhibition and for RT-PCR assays, multiple pairwise comparisons with the uninhibited or control condition, respectively, were performed by ANOVA followed by a one- or two-tailed Dunnett's test. RT-PCR data were transformed logarithmically to achieve a normal distribution before testing for significance.

\section{RESULTS}

\section{Potentiation of $\mathrm{K}^{+}$deprivation-induced apoptosis by serum deprivation}

Induction of apoptosis in CGCs was examined as a consequence of four different media conditions. Cells were incubated for varying times in control, serum-deprived, $\mathrm{K}^{+}$-deprived, or serum $/ \mathrm{K}^{+}$-deprived media. The effect of each condition on apoptotic cell death was determined both quantitatively and qualitatively. Cell death was quantified by calcein fluorescence (Fig. $1 A$ ). The number of viable cells in cultures deprived of serum for $12 \mathrm{hr}$ was decreased by $7 \pm 6 \%$ of control levels, and in $\mathrm{K}^{+}$. deprived cultures there was a $37 \pm 5 \%$ decrease in cell viability. Combined serum $/ \mathrm{K}^{+}$deprivation produced a $49 \pm 7 \%$ reduction in cell viability (Fig. $1 B$ ).

Apoptotic cell death was assessed qualitatively by DNA fragmentation analysis. Genomic DNA was extracted from cells after $12 \mathrm{hr}$ and analyzed by electrophoresis and ethidium bromide fluorescence. Although appreciable apoptotic DNA ladders were visible in $\mathrm{K} 5+\mathrm{S}$ and $\mathrm{K} 5-\mathrm{S}$ cultures, serum-deprived (K25-S) and control (K25+S) cultures produced little laddering (Fig. 1C). Previous experiments have revealed visible internucleosomal degradation by $4 \mathrm{hr}$ after serum $/ \mathrm{K}^{+}$deprivation (data not shown).

\section{Inhibition of CRCP activity in CGCs}

To determine whether CRCPs play a role in the execution of the apoptotic death program in this model, we used specific peptidefluoromethylketone inhibitors of CPP32-like or ICE-like proteases before and during serum $/ \mathrm{K}^{+}$deprivation. The effect of these inhibitors on apoptotic cell death was assessed using calcein fluorescence as described above (Fig. $2 A$ ). An increasingly protective trend was evident with z-DEVD-fmk, where cell viability compared with the $\mathrm{K} 25+\mathrm{S}$ control ranged from $59 \pm 3 \%$ at $40 \mu \mathrm{M}$ to $85 \pm 8 \%$ at $160 \mu \mathrm{M}$ (Fig. $2 B$ ). z-YVAD-fmk was ineffective at all but the highest concentration, where cell viability was $66 \pm 4 \%$ of the $\mathrm{K} 25+\mathrm{S}$ control $(p<0.05)$. Viability in the uninhibited $\mathrm{K} 5-\mathrm{S}$ condition was $51 \pm 3 \%$.

After $48 \mathrm{hr}, \mathrm{z}-\mathrm{DEVD}$-fmk continued to protect against cell death, causing viability to be $56 \pm 3 \%$ of $\mathrm{K} 25+\mathrm{S}$ control levels, whereas viability in uninhibited $\mathrm{K} 5-\mathrm{S}$ cultures was $37 \pm 3 \%$. (Fig. 2C). z-FA-fmk, which is not a specific CRCP inhibitor, was used as an additional control, and it had no significant effect on cell viability. z-YVAD-fmk was slightly toxic after $48 \mathrm{hr}$, causing a $15 \%$ reduction in cell viability beyond that of the uninhibited $\mathrm{K} 5-\mathrm{S}$ condition $(p<0.05)$.

\section{Induction of CRCP activity}

Activation of CRCPs has been implicated in numerous models of apoptotic cell death. To investigate whether these proteases may be involved in our model of apoptosis, we examined changes in CRCP activity. Protein extracts from serum- and/or $\mathrm{K}^{+}$-deprived CGC cultures were assayed for CPP32- and ICE-like protease activity using specific fluorogenic tetrapeptide substrates. As shown in Figure $3 A$, serum deprivation produced no detectable changes in the levels of CPP32-like activity during the $12 \mathrm{hr}$ of treatment. In contrast, cultures deprived of $\mathrm{K}^{+}$exhibited an elevation in CPP32-like activity beginning at $4 \mathrm{hr}$ and rising to almost $400 \%$ of control levels by $12 \mathrm{hr}$. When serum deprivation was combined with $\mathrm{K}^{+}$deprivation, the former potentiated the increases in activity induced by the latter dramatically. As early as $1 \mathrm{hr}$ after treatment, CPP32-like activity was increased by $43 \pm$ $4 \%$. At $4 \mathrm{hr}$, activity had risen to $242 \pm 18 \%$, and by $12 \mathrm{hr}$, CPP32-like protease activity was elevated more than eight times control values. A similar profile of activity was found for the in vitro cleavage of recombinant PARP, where the appearance of 89 and $24 \mathrm{kDa}$ cleavage products was most apparent in $12 \mathrm{hr} \mathrm{K}^{+}$deprived samples and 4 and $12 \mathrm{hr}$ serum $/ \mathrm{K}^{+}$-deprived samples (Fig. 3B). Although we detected considerable CPP32-like activity, the same cytosolic extracts assayed in parallel for ICE-like activity showed no cleavage of the Ac-YVAD-AMC substrate. It should be noted that the relationship between CRCP activity in vitro and in vivo are not known with certainty, and the cleavage of artificial substrates reflects an estimate of actual CRCP activity.

\section{Analysis of CPP32 and ICE mRNA content}

RT-PCR was used to determine qualitatively the presence of mRNA species for CPP32 and ICE. Although CPP32 transcripts were detectable in CGCs, ICE transcripts were not (Fig. 4). RT-PCR using whole adult rat brain mRNA, however, produced prominent amplification products for both CPP32 and ICE.

To measure changes in CPP32 mRNA content after serum and/or $\mathrm{K}^{+}$deprivation, the semiquantitative RT-PCR approach was used. As shown in Figure 5, serum deprivation caused a significant elevation in CPP32 message, which peaked at $210 \pm$ $37 \%$ of control levels after $4 \mathrm{hr}$. $\mathrm{K}^{+}$deprivation produced no significant changes in CPP32 mRNA content at any time point observed. Combined serum $/ \mathrm{K}^{+}$deprivation produced a profile similar to that of serum deprivation, in which CPP32 message content reached $173 \pm 29 \%$ of control levels at $1 \mathrm{hr}$ and peaked at $269 \pm 42 \%$ by $4 \mathrm{hr}$.

\section{Assessment of CRCP inhibitor specificity}

All members of the CRCP class cleave on the carboxyl side of aspartate residues via a Gln-Asp-Cys-Arg/Gln/Gly-Gly consensus sequence in their active sites (Martin and Green, 1995; Duan et al., 1996; Fernandes-Alnemri et al., 1996). Other residues within each holoenzyme confer a particular substrate and inhibitor specificity. According to the manufacturer, z-DEVD-fmk and z-YVAD-fmk are specific inhibitors of CPP32- and ICE-like proteases, respectively. Because both inhibitors were protective despite the absence of ICE-like activity in our cultures, we assayed the ability of z-YVAD-fmk to inhibit CPP32-like activity. z-DEVD-fmk or z-YVAD-fmk was added to THP-1 cytosolic extracts, and Ac-DEVD-AMC cleavage was measured. As expected, z-DEVD-fmk potently inhibited AMC accumulation, and as little as $20 \mu \mathrm{M}$ was sufficient to decrease activity by almost $80 \%$ (Fig. 6). z-YVAD-fmk also inhibited CPP32-like activity, although less potently than z-DEVD-fmk. At doses of $20 \mu \mathrm{M}$ 

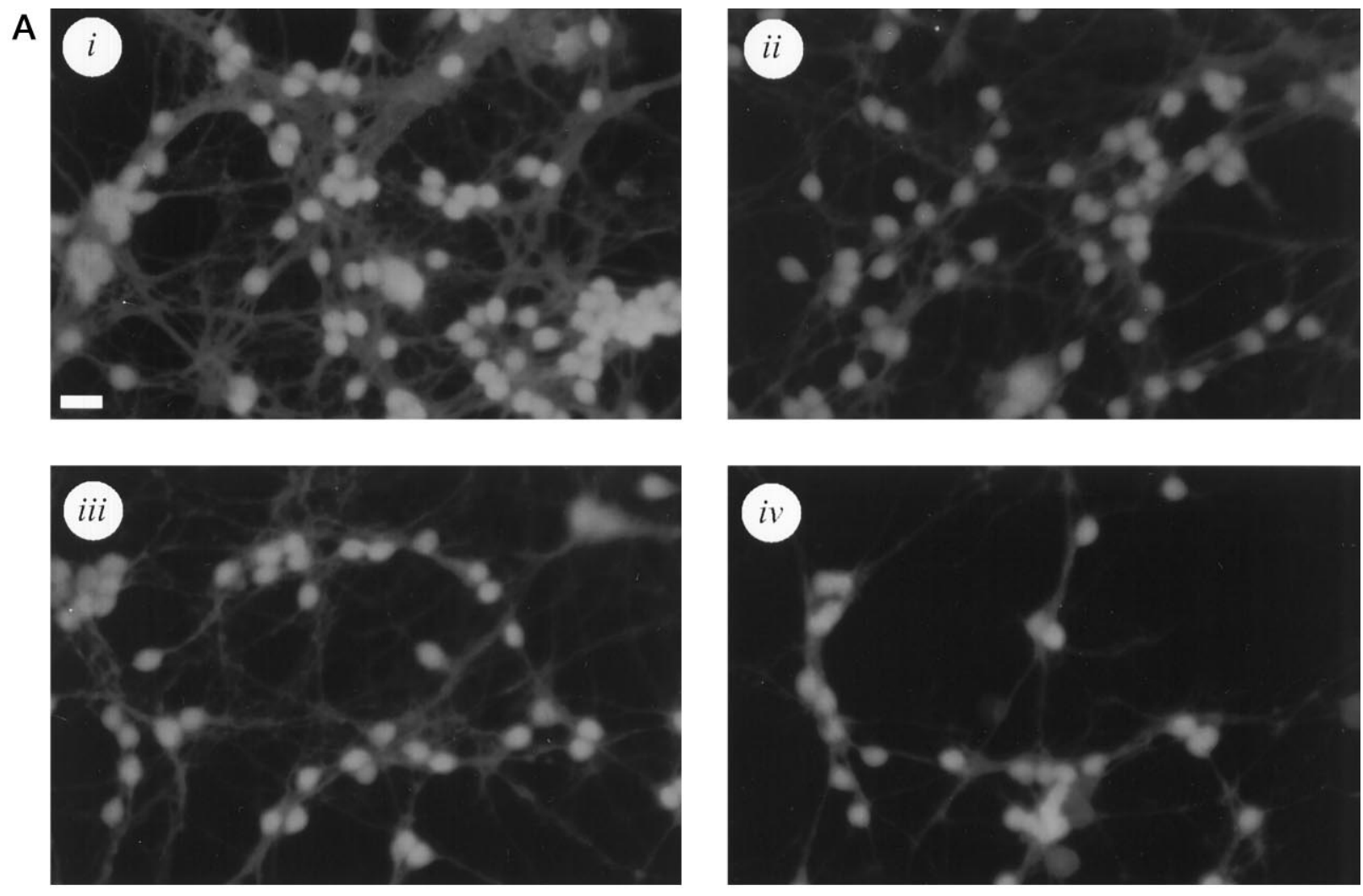

B

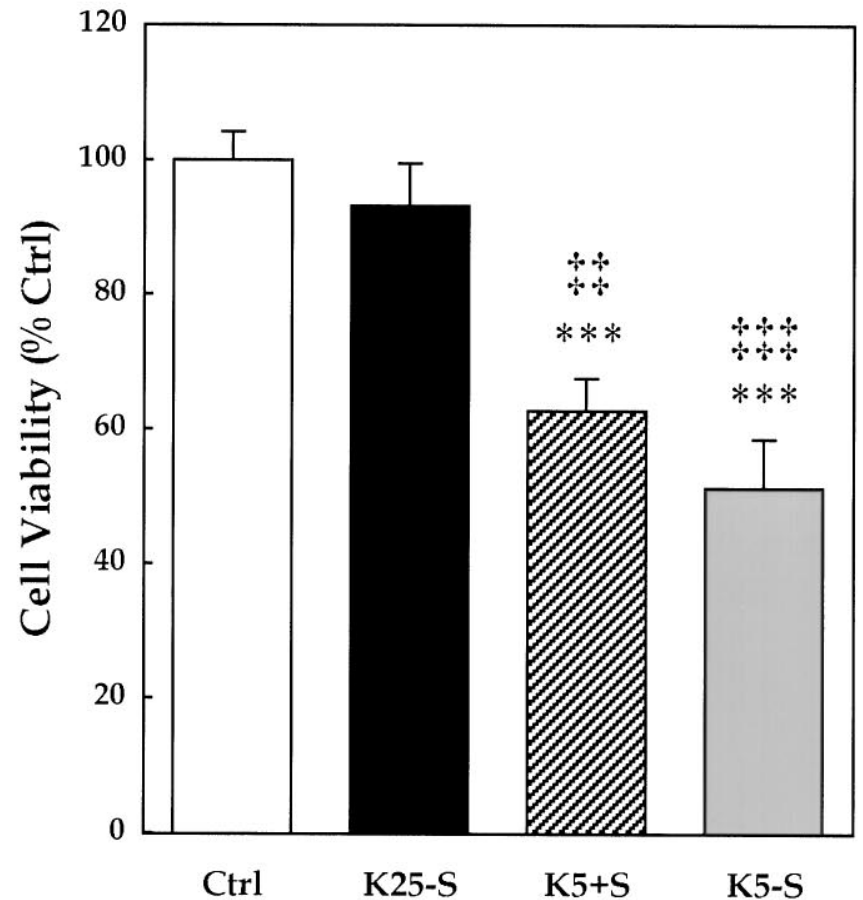

C

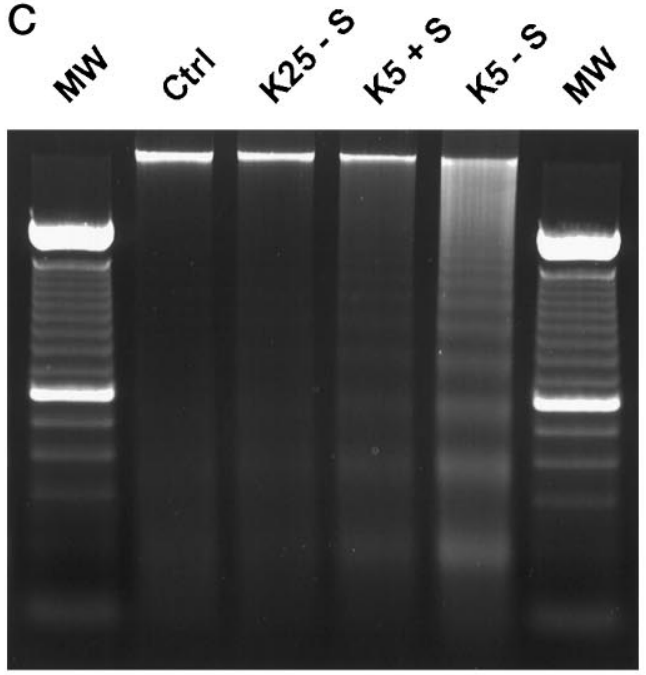

Figure 1. Apoptosis of CGCs after $12 \mathrm{hr}$ of treatment with media containing $25 \mathrm{~mm} \mathrm{KCl}$ and $10 \%$ serum (control, $\mathrm{Ctrl}$ ), $25 \mathrm{~mm} \mathrm{KCl}$ and no serum $(\mathrm{K} 25-\mathrm{S}), 5 \mathrm{mM} \mathrm{KCl}$ and $10 \%$ serum $(\mathrm{K} 5+\mathrm{S})$, or $5 \mathrm{~mm} \mathrm{KCl}$ and no serum (K5-S). A, Cells were stained with $5 \mu \mathrm{M}$ calcein AM, which is deesterified into a fluorescent product by viable cells. $i$, Control; $i i$, $\mathrm{K} 25-\mathrm{S}$; $i i i, \mathrm{~K} 5+\mathrm{S} ; i v$, $\mathrm{K} 5-\mathrm{S}$. Scale bar, $20 \mu \mathrm{m}$. $B$, Cell viability was quantified by counting the number of fluorescent cells per randomly chosen $200 \times$ field. Data are represented as the percent-to-control average number of fluorescent cells + SEM $(n=9) .{ }^{* * *} p<0.001$ compared with $C t r l ; \ddagger \neq p<0.01$ compared with K25-S; $\ddagger \ddagger \ddagger p<0.001$ compared with K25-S by ANOVA and one-tailed Tukey's test. $C$, Genomic DNA was extracted and electrophoresed in 1.5\% agarose. Internucleosomal fragmentation was most prominent in $\mathrm{K} 5+\mathrm{S}$ and $\mathrm{K} 5-\mathrm{S}$ samples, suggesting that cell death in these cultures is apoptotic. MW $=100 \mathrm{bp}$ molecular weight ladder (Life Technologies). 
A
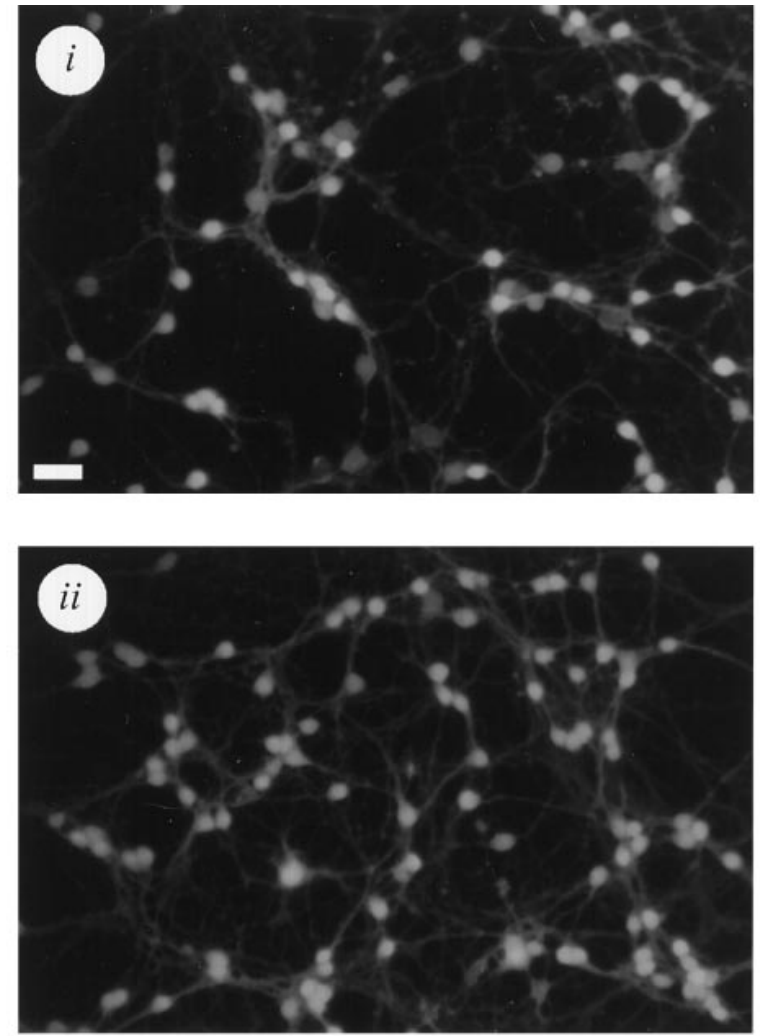

B

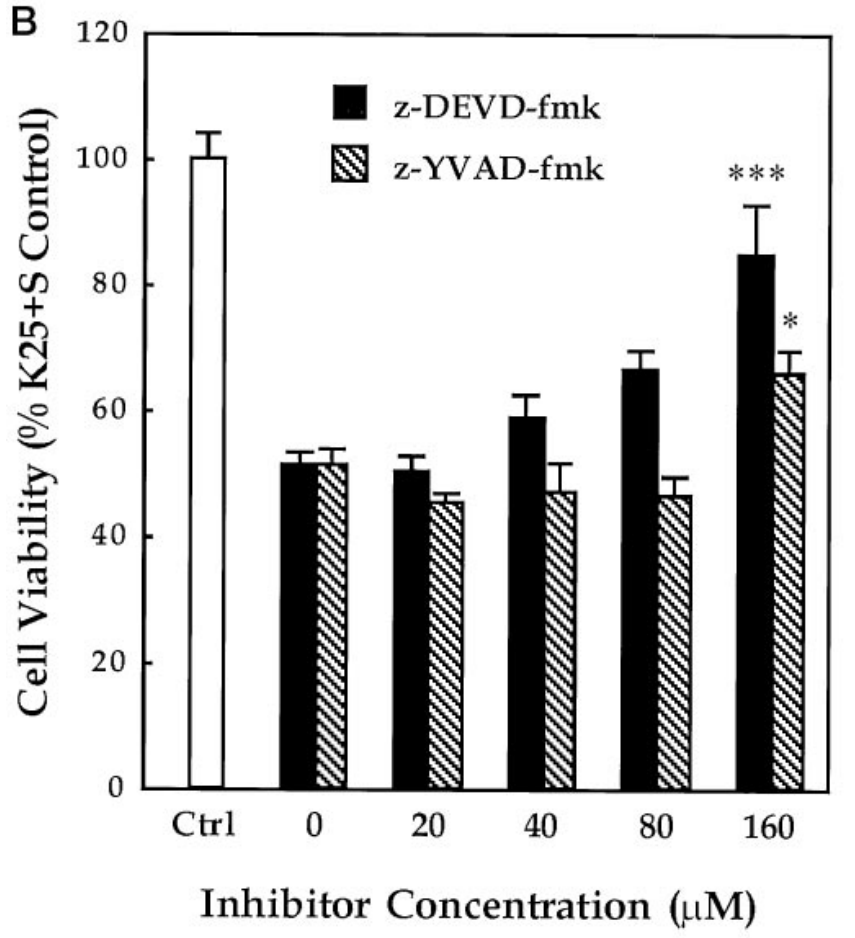

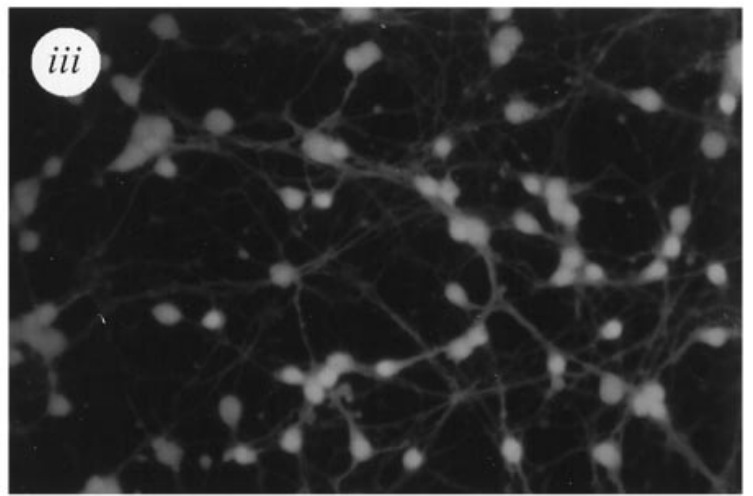

C

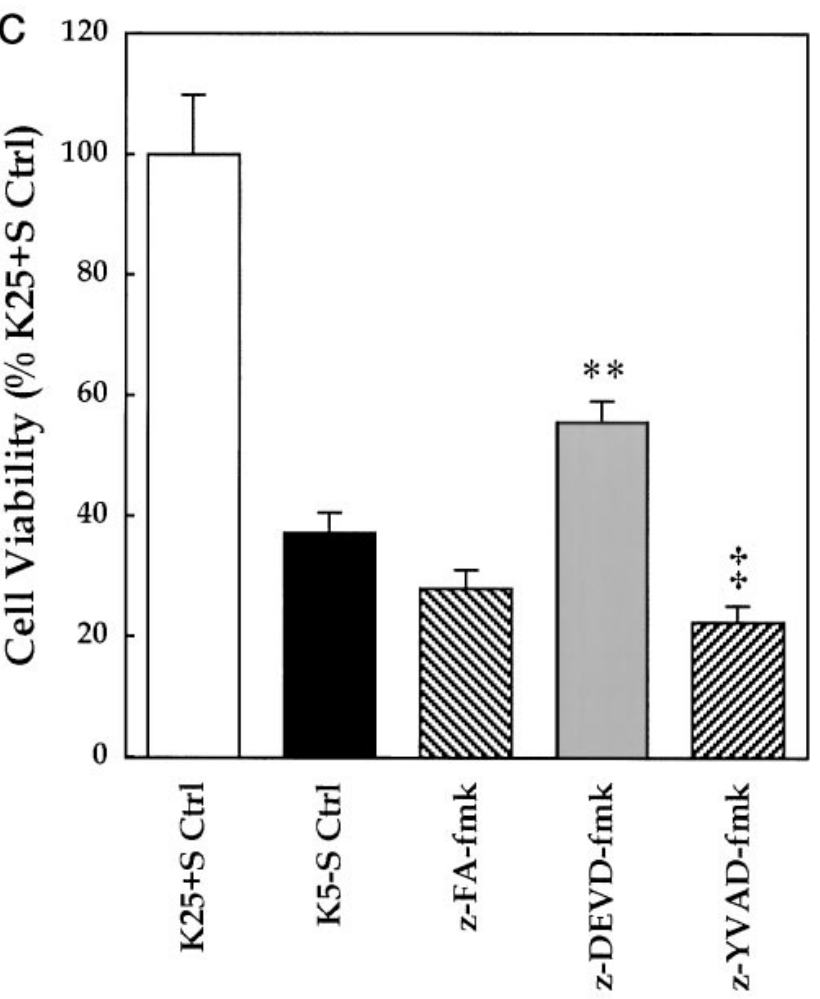

Figure 2. Protection by CRCP inhibition. The indicated concentrations of inhibitor were added to CGC cultures for $1 \mathrm{hr}$ before changing media and at the time of changing to $\mathrm{K} 5-\mathrm{S}$ media. Cultures were incubated thereafter at $37^{\circ} \mathrm{C}$. $A$, After $12 \mathrm{hr}$ incubation, cells were stained with calcein $\mathrm{AM}$ as in Figure 1A. $i, \mathrm{~K} 5-\mathrm{S}+\mathrm{DMSO}$ vehicle; $i i, \mathrm{~K} 5-\mathrm{S}+160 \mu \mathrm{M}$ z-DEVD-fmk; iii, K5-S + $160 \mu \mathrm{m}$ z-YVAD-fmk. Scale bar, $20 \mu \mathrm{m}$. $B$, Cell viability after $12 \mathrm{hr}$ incubation was quantified by calcein fluorescence as in Figure $1 B$. The average number of fluorescent cells per field + SEM is standardized to the uninhibited K25 $+\mathrm{S}$ control without vehicle ( $n=13$ for $\mathrm{z}$-DEVD-fmk; $n=8$ for z-YVAD-fmk). * $p<0.05 ; * * * p<0.001$ compared with uninhibited K5 -S cultures (0) by ANOVA and two-tailed Dunnett's test. $C$, Cell viability was quantified as above to compare the effects of z-FA-fmk, z-DEVD-fmk, and $\mathrm{z}$-YVAD-fmk at $160 \mu \mathrm{M}$ after $48 \mathrm{hr}$ incubation. The average number of fluorescent cells per field + SEM is standardized to the K25+S control $(n=$ 4). $\ddagger p<0.05 ;{ }^{* *} p<0.01$ compared with the uninhibited K5-S control by ANOVA and two-tailed Dunnett's test. 

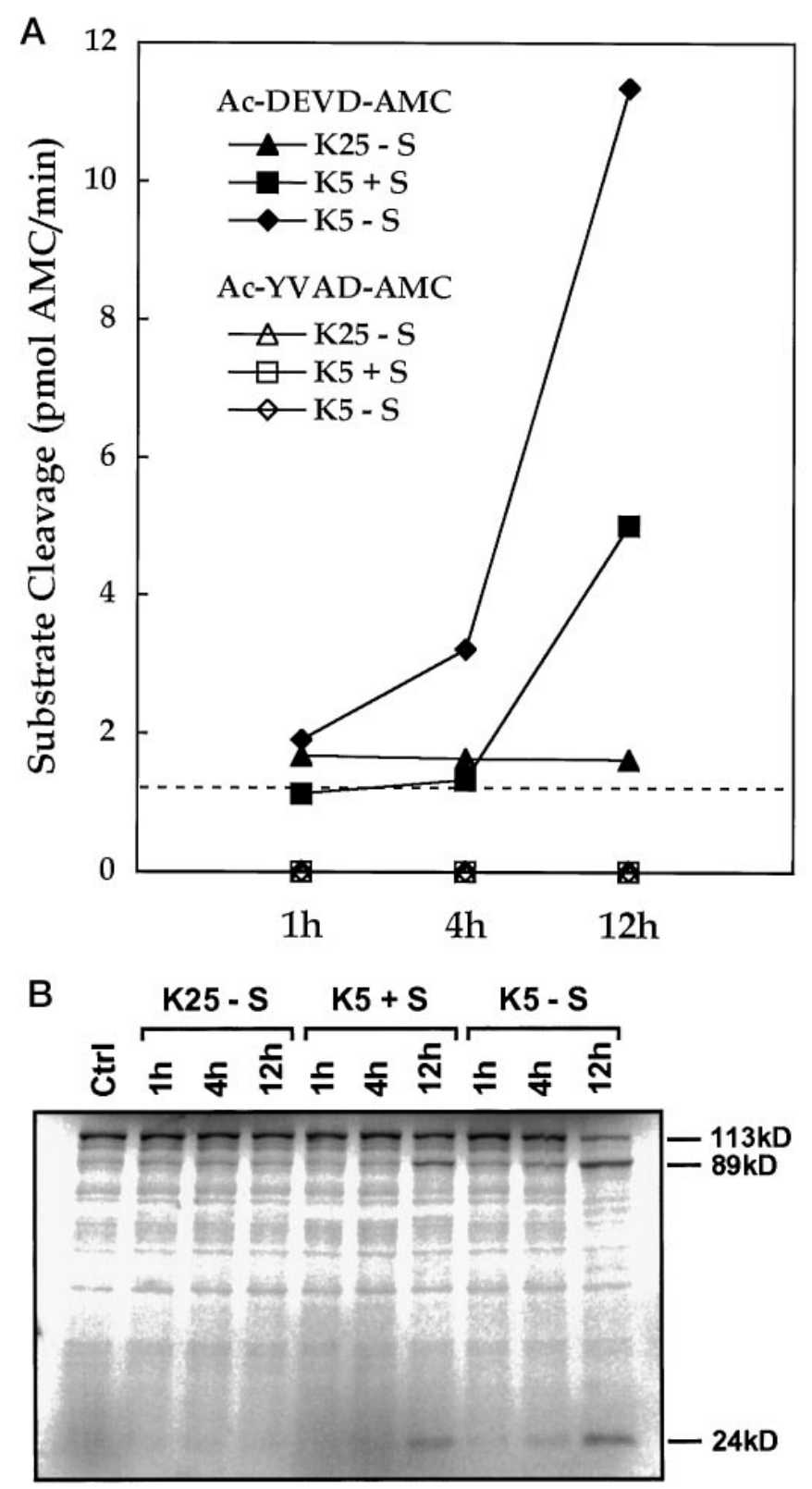

Figure 3. CRCP activity of cytosolic protein extracts from CGCs after 1, 4 , or $12 \mathrm{hr}$ of treatment with $\mathrm{K} 25+\mathrm{S}, \mathrm{K} 25-\mathrm{S}, \mathrm{K} 5+\mathrm{S}$, or $\mathrm{K} 5-\mathrm{S}$ media. $A$, Cleavage of Ac-DEVD-AMC or Ac-YVAD-AMC, substrates for CPP32or ICE-like proteases, respectively, were assayed fluorometrically by measuring the accumulation of free aminomethylcoumarin $(A M C)$. Activities are represented as the rate of AMC accumulation in $\mathrm{pmol} / \mathrm{min}$. Closed symbols represent CPP32-like activity; open symbols represent ICE-like activity (at $0 \mathrm{pmol} / \mathrm{min}$ for all time points and conditions assayed). The dashed line indicates the level of CPP32-like protease activity in $\mathrm{K} 25+\mathrm{S}$ treated cultures after $12 \mathrm{hr}$ (control). B, CPP32-like activity was confirmed by incubating protein extracts with ${ }^{35} \mathrm{~S}$-labeled recombinant PARP and analyzing the reaction products by SDS-PAGE and phosphorimagery. Bands running at $113 \mathrm{kDa}$ represent uncleaved PARP; 89 and $24 \mathrm{kDa}$ bands represent PARP cleavage products generated by CPP32-like protease activity. $C$ trl $=\mathrm{K} 25+\mathrm{S}$ treated cultures after $12 \mathrm{hr}$.

z-YVAD-fmk, AMC accumulation was reduced by only one third of initial levels. Increasing concentrations progressively decreased proteolytic activity, and at $160 \mu \mathrm{M} \mathrm{z}$-YVAD-fmk, AMC accumulation was $\sim 20 \%$ of uninhibited values. z-FA-fmk showed marked effects at only the highest concentrations, where it decreased CPP32-like activity by one third.

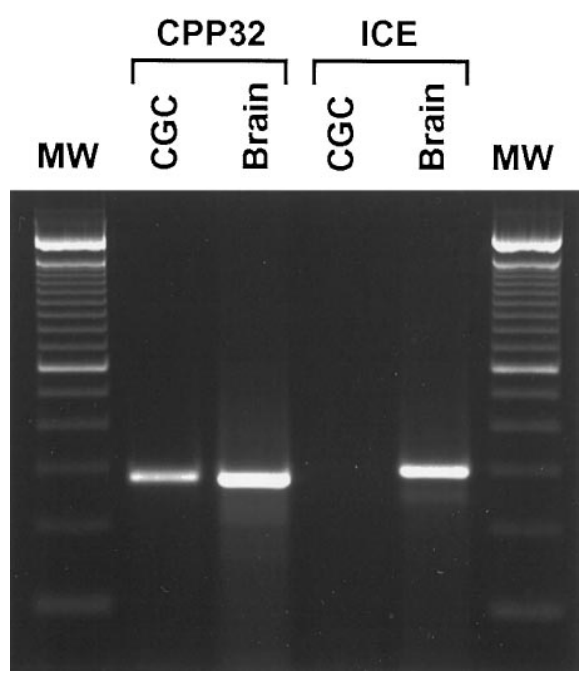

Figure 4. Qualitative RT-PCR for CPP32 and ICE mRNA. cDNA from CGCs or whole adult rat brain were amplified by 30 cycles of PCR. Reaction products were electrophoresed in $2 \%$ agarose and visualized by ethidium bromide fluorescence. CPP32 mRNA was detectable in both CGCs and whole adult rat brain; however, ICE mRNA was detectable only in adult rat brain. $\mathrm{MW}=100 \mathrm{bp}$ molecular weight ladder (Life Technologies).

\section{DISCUSSION}

\section{Apoptosis resulting from serum and/or $\mathrm{K}^{+}$deprivation}

Serum deprivation had little effect on cell death after $12 \mathrm{hr}$, which is consistent with the work of Atabay et al. (1996); however, $\mathrm{K}^{+}$ deprivation substantively increased the degree of death, and combined serum $/ \mathrm{K}^{+}$deprivation caused a further cell death trend. Recent evidence suggests that serum or $\mathrm{K}^{+}$deprivation alone may induce apoptosis through different biochemical mechanisms. Apoptosis under low $\mathrm{K}^{+}$conditions can be prevented by the addition of glutamate or NMDA (Balázs et al., 1988; Yan et al., 1994), indicating that stimulation of ionotropic glutamate receptors may provide an anti-apoptotic signal. Consistent with this view is the observation that the noncompetitive NMDA receptor antagonist MK-801 (dizolcipine) can block the protective effects of glutamate or NMDA (Yan et al., 1994). In contrast, apoptosis after serum deprivation is prevented by MK-801 (Atabay et al., 1996), and brief withdrawal of serum with concomitant glutamate exposure can cause delayed apoptosis (Ankacrona et al., 1995). These seemingly contradictory actions of glutamate may be explained in part by the recent findings of Miller and Johnson (1996), who described a heterogeneous distribution of neurons in CGC cultures. One population of cells dies rapidly in response to serum deprivation, whereas the other is killed by $\mathrm{K}^{+}$deprivation in a delayed fashion. The existence of two populations of cells and the contrasting effects of glutamate receptor stimulation on different apoptotic stimuli indicate that more than one pathway may be involved in mediating CGC apoptosis.

\section{Effects of fluoromethylketone inhibitors of CRCPs}

Because the peptide inhibitor z-DEVD-fmk exerted both shortterm and long-term protective effects after serum $/ \mathrm{K}^{+}$deprivation, the apoptotic pathway after this stimulus likely involves CRCPs. This result is consistent with the recent findings of Kuida et al. (1996), who showed that CPP32-nullizygotes exhibit gross deficiencies in apoptosis resulting in highly aberrant developmen- 


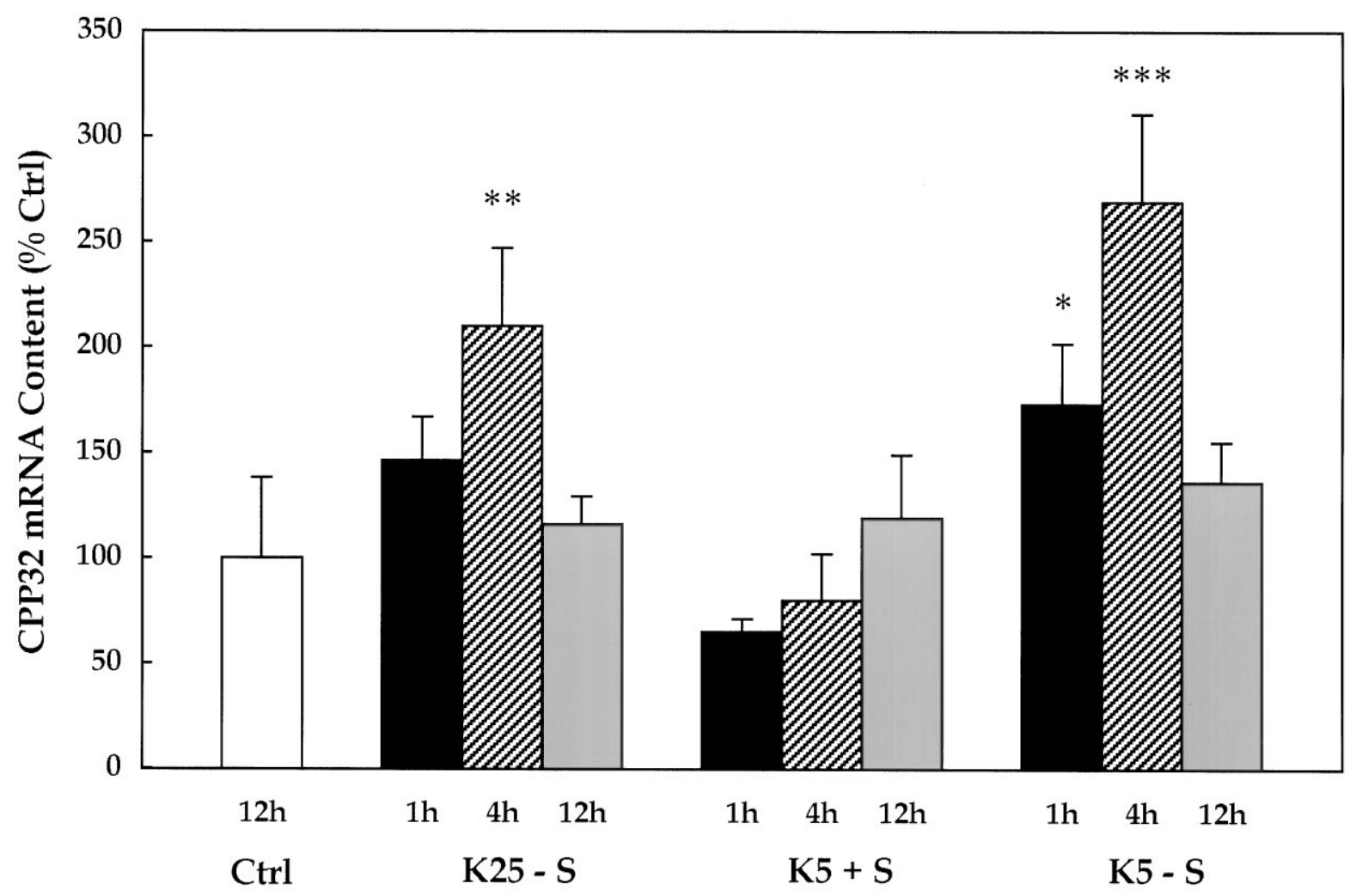

Figure 5. Semiquantitative RT-PCR for CPP32 after 1, 4, or $12 \mathrm{hr}$ of treatment with K25+S, K25-S, K5+S, or K5-S media. CPP32-to-histone 4G band volume ratios were averaged for each time point to produce a mean volume ratio $(n=6)$. mRNA content is expressed as the percent-to-control of mean volume ratio $+\mathrm{SEM}$, where control $(\mathrm{Ctrl})$ is $\mathrm{K} 25+\mathrm{S}$ treated cultures at $12 \mathrm{hr}$. CPP32 mRNA levels peaked after $4 \mathrm{hr}$ of serum and serum $/ \mathrm{K}^{+}$withdrawal but did not change significantly after $\mathrm{K}^{+}$deprivation. ${ }^{*} p<0.05 ;{ }^{* *} p<0.01$; ${ }^{* * *} p<0.001$ compared with control by ANOVA and Dunnett's test.

tal features, one of which is an abnormally high concentration of granule cells in the developing cerebellum. CPP32-like proteases have also been shown to play a critical role in the progression of apoptosis in other systems. For example, Fas- and TNF $\alpha$ mediated cytotoxicity in lymphocytes can be blocked by selective inhibition of CPP32-like proteases, and studies have implicated the CPP32-like protease FLICE/MACH as the most upstream mediator in this model (Boldin et al., 1996; Muzio et al., 1996).

The ICE-like inhibitor z-YVAD-fmk did not affect cell viability after $12 \mathrm{hr}$ of serum/ $\mathrm{K}^{+}$deprivation between 20 and $80 \mu \mathrm{M}$ and showed only slight protective effects at $160 \mu \mathrm{M}$. At this highest concentration, it is likely that z-YVAD-fmk was acting as a nonspecific CRCP inhibitor for several reasons. First, ICE-like activity was absent in our system, thus obviating an enzyme target for this inhibitor. Second, z-YVAD-fmk failed to protect cells after $48 \mathrm{hr}$ of serum $/ \mathrm{K}^{+}$deprivation. Finally, at high enough concentrations the fluoromethylketone (fmk) group of these inhibitors can nonspecifically attack the active cysteine of any CRCP. This could explain why z-YVAD-fmk, as well as z-FAfmk, inhibited Ac-DEVD-AMC cleavage moderately in vitro (Fig. 6). Conversely, it is likely that z-DEVD-fmk was acting as a specific inhibitor of CPP32-like because it had the highest potency of CPP32-like inhibition in vitro, it provided greater protection after $12 \mathrm{hr}$ of serum $/ \mathrm{K}^{+}$deprivation, and it retained these protective effects after $48 \mathrm{hr}$.

It should be noted that the concentrations of inhibitors in the in vitro fluorometric assay are expected to be much greater than their intracellular concentrations in CGC cultures because of the net positive charges of aspartate and glutamate residues and the

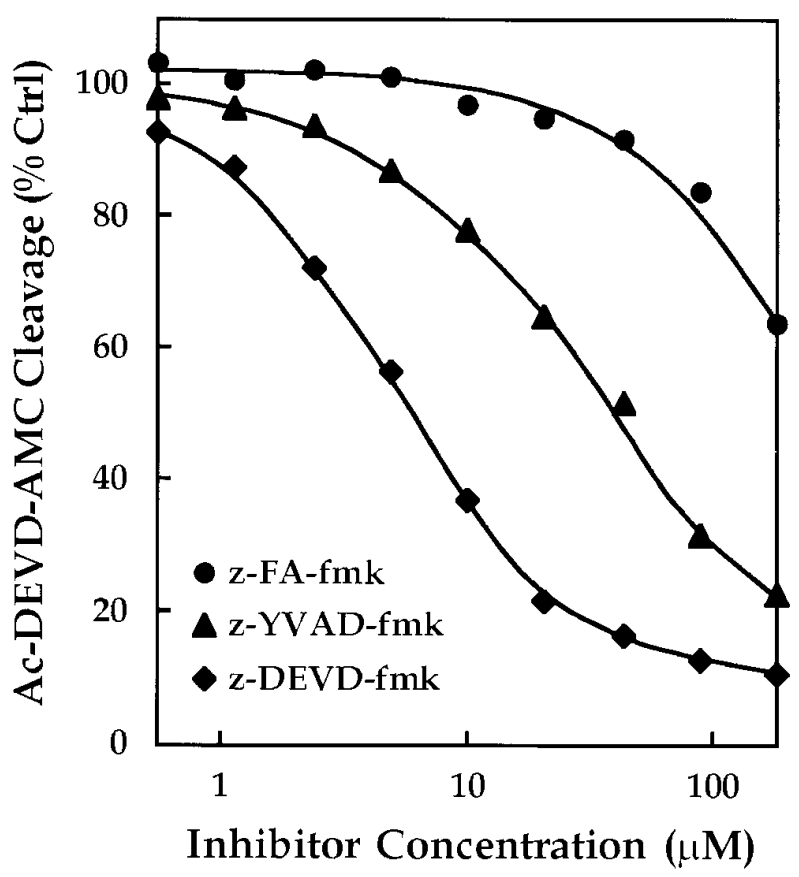

Figure 6. Inhibition of CPP32-like protease activity in vitro. Cytoplasmic protein extracts from etoposide-treated THP-1 cells were incubated with increasing concentrations of z-DEVD-fmk (diamonds), z-YVAD-fmk (triangles), or z-FA-fmk (circles). Cleavage of the CPP32-like substrate AcDEVD-AMC was assayed fluorometrically as in Figure $3 A$. Data are standardized to the rate of cleavage in DMSO-treated extracts $(100 \%)$. 
polarity of the fmk groups. Such characteristics increase the hydrophilicity of these inhibitors and hence decrease their ability to penetrate cell membranes.

That z-FA-fmk and z-YVAD-fmk increased cell death slightly after $48 \mathrm{hr}$ suggests that the $\mathrm{z}$ - or fmk groups may be toxic when present for extended periods of time. The fmk group in particular may reduce cell survival by nonspecific interactions with the cysteine residues of various proteins. That $\mathrm{z}$-DEVD-fmk was protective despite such putative toxic effects lends further support to its role as a specific CRCP inhibitor; however, because its protective effects were incomplete, it is likely that other pathways may also be important to the apoptotic death program.

\section{CPP32-like activity and CPP32 mRNA content}

CRCPs are initially translated as pro-enzymes and are subsequently transformed into active heterodimeric complexes though a cascade of proteolytic events (Martin and Green, 1995; Alnemri et al., 1996). As such, an increase in CPP32-like activity can be accounted for by an increase in transcription/translation of the pro-enzyme and/or an increase in other activating proteases.

In cultures deprived of either serum or $\mathrm{K}^{+}$, we found dissimilar trends between CPP32 mRNA content and CPP32-like activity. CPP32 mRNA content was elevated after $4 \mathrm{hr}$ of serum deprivation, whereas it was essentially unchanged during $12 \mathrm{hr}$ of $\mathrm{K}^{+}$ deprivation. On the other hand, CPP32-like activity was unchanged after serum deprivation, but it was increased significantly after $12 \mathrm{hr}$ of $\mathrm{K}^{+}$deprivation, similar to recently reported findings (Ni et al., 1996; Armstrong et al., 1997). Although intermediate time points between 4 and $12 \mathrm{hr}$ could present better correlations between mRNA and enzymatic activity, it is possible that at the time points examined, other CRCPs in addition to CPP32 contribute to the observed increases in DEVD cleavage activity. One proposed mechanism by which these other proteases could be involved is as follows. CPP32 pro-enzyme may be proteolytically activated by some other CPP32-like protease. MCH2 $\alpha$ (Liu et al., 1996) and MCH4 (Fernandes-Alnemri et al., 1996) have both been shown to perform this function, and the increase in CPP32-like activity after $\mathrm{K}^{+}$deprivation may reflect increases in $\mathrm{MCH} 2 \alpha$ or $\mathrm{MCH} 4$ activity. Serum deprivation causes an increase in CPP32 mRNA levels and therefore a likely increase in CPP32 pro-enzyme levels. When serum and $\mathrm{K}^{+}$deprivation are combined, the result is a potentiated increase in CPP32-like activity as shown in Figure 3.

In some non-neuronal systems, the role of CPP32 activator has been attributed to granzyme B (Darmon et al., 1995; Quan et al., 1996) or ICE (Tewari et al., 1995; Enari et al., 1996). Insofar as ICE is concerned, the results of the present study suggest that other proteases must activate CPP32 in CGCs, because contrary to the findings of Schulz et al. (1996) neither ICE mRNA nor ICE-like activity were detectable. This is consistent with the observations of other investigators who have also failed to find a role for ICE in neuronal apoptosis. For example, in ICEnullizygous mice, central and peripheral nervous structures appear to develop normally (Kuida et al., 1995). Likewise, PC12 cells undergo apoptosis after nerve growth factor withdrawal, but they too contain no detectable ICE-like activity (BozyczkoCoyne et al., 1996). As for granzyme B, it remains to be determined whether this protease plays a role in apoptosis of CGCs.

\section{Conclusions}

The present studies demonstrate a potentiating effect of serum deprivation on apoptosis induced by withdrawal of $\mathrm{K}^{+}$in CGCs and support an important role for CPP32-like CRCPs in this process. The identification of the sequences for other CRCPs in the rat, as well as the development of selective inhibitors of specific CRCPs, should clarify which CPP32-like proteases contribute to apoptosis in CGCs.

\section{REFERENCES}

Alnemri ES, Livingston DJ, Nicholson DW, Salvesen G, Thornberry NA, Wong WW, Yuan J (1996) Human ICE/CED-3 protease nomenclature. Cell 87:171.

Ankarcrona M, Dypbukt JM, Bonfoco E, Zhivotovsky B, Orrenius S, Lipton SA, Nicotera P (1995) Glutamate-induced neuronal death: a succession of necrosis or apoptosis depending on mitochondrial function. Neuron 15:961-973.

Armstrong RC, Aja TJ, Hoang KD, Gaur S, Bai X, Alnemri ES, Litwack G, Karanewsky DS, Fritz LC, Tomaselli KJ (1997) Activation of the CED3/ICE-related protease CPP32 in cerebellar granule neurons undergoing apoptosis but not necrosis. J Neurosci 17:553-562.

Atabay C, Cagnoli CM, Kharlamov E, Ikonomovic MD, Manev H (1996) Removal of serum from primary cultures of cerebellar granule neurons induces oxidative stress and DNA fragmentation: protection with antioxidants and glutamate receptor antagonists. J Neurosci Res 43: 465-475.

Balázs R, Jørgensen OS, Hack N (1988) N-methyl-D-aspartate promotes the survival of cerebellar granule cells in culture. Neuroscience 27:437-451.

Batistatou A, Greene LA (1993) Internucleosomal DNA cleavage and neuronal cell survival/death. J Cell Biol 122:523-532.

Boldin MP, Goncharov TM, Goltsev YV, Wallach D (1996) Involvement of MACH, a novel MORT1/FADD-interacting protease, in Fas/ APO-1- and TNF receptor-induced cell death. Cell 85:803-815.

Bozyczko-Coyne D, Dobrzanski P, Meyer S, O'Kane T, Carswell S, Scott RW, Siman R (1996) ICE-related proteases involved in growth factor deprivation-induced neuronal apoptosis. Soc Neurosci Abstr 22:566.

Bredesen DE (1995) Neural apoptosis. Ann Neurol 38:839-851.

Casciola-Rosen L, Nicholson DW, Chong T, Rowan KR, Thornberry NA, Miller DK, Rosen A (1996) Apopain/CPP32 cleaves proteins that are essential for cellular repair: a fundamental principle of apoptotic death. J Exp Med 183:1957-1964.

Chomczynski P, Sacchi N (1987) Single-step method of RNA isolation by acid guanidinium thiocyanate-phenol-chloroform extraction. Anal Biochem 162:156-159.

Darmon AJ, Nicholson DW, Bleackley RC (1995) Activation of the apoptotic protease CPP32 by cytotoxic T-cell-derived granzyme B. Nature 377:446-448.

D’Mello SR, Galli C, Ciotti T, Calissano P (1993) Induction of apoptosis in cerebellar granule neurons by low potassium: inhibition of death by insulin-like growth factor I and cAMP. Proc Natl Acad Sci USA 90:10989-10993.

Duan H, Orth K, Chinnaiyan AM, Poirier GG, Froelich CJ, He W-W, Dixit VM (1996) ICE-LAP6, a novel member of the ICE/Ced-3 gene family, is activated by the cytotoxic T cell protease granzyme B. J Biol Chem 271:16720-16724.

Eldadah BA, Yakovlev AG, Faden AI (1996) A new approach for the electrophoretic detection of apoptosis. Nucleic Acids Res 24:4092-4093.

Ellis HM, Horvitz HR (1986) Genetic control of programmed cell death in the nematode C. elegans. Cell 44:817-829.

Enari M, Talanian RV, Wong WW, Nagata S (1996) Sequential activation of ICE-like and CPP32-like proteases during Fas-mediated apoptosis. Nature 380:723-726.

Faucheu C, Diu A, Chan AWE, Blanchet A-M, Miossec C, Hervé F, Collard-Dutilleul V, Gu Y, Aldape RA, Lippke JA, Rocher C, Su MS-S, Livingston DJ, Hercend T, Lalanne J-L (1995) A novel human protease similar to the interleukin $1 \beta$-converting enzyme induces apoptosis in transfected cells. EMBO J 14:1914-1922.

Fernandes-Alnemri T, Litwack G, Alnemri ES (1994) CPP32, a novel human apoptotic protein with homology to Caenorhabditis elegans cell death protein ced- 3 and mammalian interleukin-1 $\beta$-converting enzyme. J Biol Chem 269:30761-30764.

Fernandes-Alnemri T, Litwack G, Alnemri ES (1995a) Mch2, a new member of the apoptotic Ced-3/Ice cysteine protease gene family. Cancer Res 55:2737-2742.

Fernandes-Alnemri T, Litwack G, Alnemri ES (1995b) Mch3, a novel 
human apoptotic cysteine protease highly related to CPP32. Cancer Res 55:6045-6052.

Fernandes-Alnemri T, Armstrong RC, Krebs J, Srinivasula SM, Wang L, Bullrich F, Fritz LC, Trapani JA, Tomaselli KJ, Litwack G, Alnemri ES (1996) In vitro activation of CPP32 and Mch3 by Mch4, a novel human apoptotic cysteine protease containing two FADD-like domains. Proc Natl Acad Sci USA 93:7464-7469.

Gavrieli Y, Sherman Y, Ben-Sasson SA (1992) Identification of programmed cell death in situ via specific labeling of nuclear DNA fragmentation. J Cell Biol 119:493-501.

Hartley A, Stone JM, Heron C, Cooper JM, Schapira AHV (1994) Complex I inhibitors induce dose-dependent apoptosis in PC12 cells: relevance to Parkinson's disease. J Neurochem 63:1987-1990.

Jacobson MD, Weil M, Raff MC (1996) Role of ced-3/ICE-family proteases in staurosporine-induced programmed cell death. J Cell Biol 133:1041-1051.

Kamens J, Paskind M, Hugunin M, Talanian RV, Allen H, Banach D, Bump N, Hackett M, Johnston CG, Li P, Mankovich JA, Terranova M, Ghayur T (1995) Identification and characterization of ICH-2, a novel member of the interleukin- $1 \beta$ converting enzyme family of cysteine proteases. J Biol Chem 270:15250-15256.

Kaufmann SH, Desnoyers S, Ottaviano Y, Davidson ND, Poirier GG (1993) Specific proteolytic cleavage of poly(ADP-ribose) polymerase: an early marker of chemotherapy-induced apoptosis. Cancer Res 53:3976-3985.

Kayalar C, Örd T, Testa MP, Zhong LT, Bredesen DE (1996) Cleavage of actin by interleukin $1 \beta$-converting enzyme to reverse DNase I inhibition. Proc Natl Acad Sci USA 93:2234-2238.

Kerr JFR, Wyllie AH, Currie AR (1972) Apoptosis: a basic biological phenomenon with wide-ranging implications in tissue kinetics. $\mathrm{Br} \mathrm{J}$ Cancer 26:239-257.

Kuida K, Lippke JA, Ku G, Harding MW, Livingston DJ, Su MS-S, Flavell RA (1995) Altered cytokine export and apoptosis in mice deficient in interleukin-1 $\beta$ converting enzyme. Science 267:2000-2003.

Kuida K, Zheng TS, Na S, Kuan C-Y, Yang D, Karasuyama H, Rakic P, Flavell RA (1996) Decreased apoptosis in the brain and premature lethality in CPP32-deficient mice. Nature 384:368-372.

Kumar S, Kinoshita M, Noda M, Copeland NG, Jenkins NA (1994) Induction of apoptosis by the mouse Nedd2 gene, which encodes a protein similar to the product of the Caenorhabditis elegans cell death gene $c e d-3$ and the mammalian IL- $1 \beta$-converting enzyme. Genes Dev 8:1613-1626.

Li Y, Sharov VG, Jiang N, Zaloga C, Sabbah HN, Chopp N (1995) Ultrastructural and light microscopic evidence of apoptosis after middle cerebral artery occlusion in the rat. Am J Pathol 146:1045-1051.

Linnik MD, Zobrist RH, Hatfield MD (1993) Evidence supporting a role for programmed cell death in focal cerebral ischemia in rats. Stroke 24:2002-2009.

Liu X, Kim CN, Pohl J, Wang X (1996) Purification and characterization of an interleukin- $1 \beta$-converting enzyme family protease that activates cysteine protease P32 (CPP32). J Biol Chem 271:13371-13376.

Martin SJ, Green DR (1995) Protease activation during apoptosis: death by a thousand cuts? Cell 82:349-352.

Miller TM, Johnson EM (1996) Metabolic and genetic analyses of apoptosis in potassium/serum-deprived rat cerebellar granule cells. J Neurosci 16:7487-7495.

Munday NA, Vaillancourt JP, Ali A, Casano FJ, Miller DK, Molineaux SM, Yamin T-T, Yu VL, Nicholson DW (1995) Molecular cloning and pro-apoptotic activity of ICE $\mathrm{rel}_{\mathrm{rI}} \mathrm{I}$ and $\mathrm{ICE}_{\mathrm{rel}} \mathrm{III}$, members of the ICE/ CED-3 family of cysteine proteases. J Biol Chem 270:15870-15876.

Muzio M, Chinnaiyan AM, Kischkel FC, O'Rourke K, Shevchenko A, Ni J, Scaffidi C, Bretz JD, Zhang M, Gentz R, Mann M, Krammer PH, Peter ME, Dixit VM (1996) FLICE, a novel FADD-homologous ICE/
CED-3-like protease, is recruited to the CD95 (Fas/APO-1) deathinducing signaling complex. Cell 85:817-827.

Ni B, Wu X, Du Y, Hamilton-Byrd E, Rockey PK, Rosteck Jr P, Poirier GG, Su Y, Paul SM (1996) Cloning and expression of a rat brain ICE-related protease (IRP) and role in $\mathrm{KCl}$ deficiency-mediated apoptosis of cultured cerebellar granule cells. Soc Neurosci Abstr 22:567.

Nicholson DW, Ali A, Thornberry NA, Vaillancourt JP, Ding CK, Gallant M, Gareau Y, Griffin PR, Labelle M, Lazebnik YA, Munday NA, Raju SM, Smulson ME, Yamin T-T, Yu VL, Miller DK (1995) Identification and inhibition of the ICE/CED-3 protease necessary for mammalian apoptosis. Nature 376:37-43.

Oppenheim RW (1991) Cell death during development of the nervous system. Annu Rev Neurosci 14:453-501.

Portera-Cailliau C, Hedreen JC, Price DL, Koliatsos VE (1995) Evidence for apoptotic cell death in Huntington disease and excitotoxic animal models. J Neurosci 15:3775-3787.

Quan LT, Tewari M, O’Rourke K, Dixit V, Snipas SJ, Poirier GG, Ray C, Pickup DJ, Salvesen GS (1996) Proteolytic activation of the cell death protease Yama/CPP32 by granzyme B. Proc Natl Acad Sci USA 93:1972-1976.

Rabizadeh S, Gralla EB, Borchelt DR, Gwinn R, Valentine JS, Sisodia S, Wong P, Lee M, Hahn H, Bredesen DE (1995) Mutations associated with amyotrophic lateral sclerosis convert superoxide dismutase from an antiapoptotic gene to a proapoptotic gene: studies in yeast and neural cells. Proc Natl Acad Sci USA 92:3024-3028.

Rink A, Fung K-M, Trojanowski JQ, Lee, V M-Y, Neugebauer E, McIntosh TK (1995) Evidence of apoptotic cell death after experimental traumatic brain injury in the rat. Am J Pathol 147:1575-1583.

Schramm M, Eimerl S, Costa E (1990) Serum and depolarizing agents cause acute neurotoxicity in cultured cerebellar granule cells: role of the glutamate receptor responsive to $N$-methyl-D-aspartate. Proc Natl Acad Sci USA 87:1193-1197.

Schulz JB, Weller M, Klockgether T (1996) Potassium deprivationinduced apoptosis of cerebellar granule neurons: a sequential requirement for new mRNA and protein synthesis, ICE-like protease activity, and reactive oxygen species. J Neurosci 16:4696-4706.

Tewari M, Quan LT, O'Rourke K, Desnoyers S, Zeng Z, Beidler DR, Dixit VM (1995) Yama/CPP32 $\beta$, a mammalian homolog of CED-3 is a crmA-inhibitable protease that cleaves the death substrate poly(ADPribose) polymerase. Cell 81:801-809.

Thangnipon W, Kingsbury A, Webb M, Balazs R (1983) Observations on rat cerebellar cells in vitro: influence of substratum, potassium concentration and relationship between neurones and astrocytes. Dev Brain Res 11:177-189.

Thornberry NA, Bull HG, Calaycay JR, Chapman KT, Howard AD, Kostura MJ, Miller DK, Molineaux SM, Weidner JR, Aunins J, Elliston KO, Ayala JM, Casano FJ, Chin J, Ding GJ-F, Egger LA, Gaffney EP, Limjuco G, Palyha OC, Raju SM, Rolando AM, Salley JP, Yamin T-T, Lee TD, Shively JE, MacCross M, Mumford RA, Schmidt JA, Tocci MJ (1992) A novel heterodimeric cysteine protease is required for interleukin-1 $\beta$ processing in monocytes. Nature 356:768-774.

Wang L, Miura M, Bergeron L, Zhu H, Yuan J (1994) Ich-1, an Ice/ Ced-3-related gene, encodes both positive and negative regulators of programmed cell death. Cell 78:739-750.

Wyllie AH (1980) Glucocorticoid-induced thymocyte apoptosis is associated with endogenous endonuclease activation. Nature 284:555-556.

Yan G-M, Ni B, Weller M, Wood K, Paul SM (1994) Depolarization or glutamate receptor activation blocks apoptotic cell death of cultured cerebellar granule neurons. Brain Res 656:43-51.

Zhu H, Fearnhead HO, Cohen GM (1995) An ICE-like protease is a common mediator of apoptosis induced by diverse stimuli in human monocytic THP.1 cells. FEBS Lett 374:303-308. 